IZA DP No. 9342

Fertility, Household Structure, and Parental Labor Supply: Evidence from Rural China

Hongbin $\mathrm{Li}$

Junjian Yi

Junsen Zhang

September 2015 


\title{
Fertility, Household Structure, and Parental Labor Supply: Evidence from Rural China
}

\author{
Hongbin Li \\ Tsinghua University and IZA \\ Junjian Yi \\ National University of Singapore and IZA \\ Junsen Zhang \\ Chinese University of Hong Kong and IZA
}

Discussion Paper No. 9342

September 2015

\author{
IZA \\ P.O. Box 7240 \\ 53072 Bonn \\ Germany \\ Phone: +49-228-3894-0 \\ Fax: +49-228-3894-180 \\ E-mail: iza@iza.org
}

Any opinions expressed here are those of the author(s) and not those of IZA. Research published in this series may include views on policy, but the institute itself takes no institutional policy positions. The IZA research network is committed to the IZA Guiding Principles of Research Integrity.

The Institute for the Study of Labor (IZA) in Bonn is a local and virtual international research center and a place of communication between science, politics and business. IZA is an independent nonprofit organization supported by Deutsche Post Foundation. The center is associated with the University of Bonn and offers a stimulating research environment through its international network, workshops and conferences, data service, project support, research visits and doctoral program. IZA engages in (i) original and internationally competitive research in all fields of labor economics, (ii) development of policy concepts, and (iii) dissemination of research results and concepts to the interested public.

IZA Discussion Papers often represent preliminary work and are circulated to encourage discussion. Citation of such a paper should account for its provisional character. A revised version may be available directly from the author. 
IZA Discussion Paper No. 9342

September 2015

\section{ABSTRACT}

\section{Fertility, Household Structure, and Parental Labor Supply: Evidence from Rural China*}

This paper tests the effects of fertility on household structure and parental labor supply in rural China. To solve the endogeneity problem, we use a unique survey on households with twin children and a comparison group of non-twin households. The ordinary least squares estimates show a negative correlation between fertility and parental labor supply. Using twinning as a natural experiment, we do not find evidence on the negative effects of fertility on parental labor supply. By contrast, we find that the twinning-induced increase in fertility enhances significantly the coresidence of grandparents. The results remain robust when we use the Chinese 1990 population census. We suggest that the negative effects of fertility on parental labor supply are mitigated by the childcare provided by grandparents. Our results have important implications for population and public childcare policies.

JEL Classification: J13, J18, J22, O10

Keywords: fertility, parental labor supply, household structure

Corresponding author:

Junjian Yi

Department of Economics

Faculty of Arts \& Social Sciences

National University of Singapore

AS2 Level 6, 1 Arts Link

Singapore 117570

Singapore

E-mail: junjian@nus.edu.sg

\footnotetext{
* We would like to thank James Heckman and Robert Pollak for their valuable comments and suggestions.
} 


\section{Introduction}

Standard economic models predict a negative effect of fertility on parental labor supply, especially mothers' (Borjas, 2000), because parents need to allocate time to childcare. Such models assume a nuclear family, in which the only adults who can provide labor are parents. These models fit well for data from developed countries (Killingsworth \& Heckman, 1986, Angrist \& Evans, 1998), 1] but less so for data from developing countries (Cruces \& Galiani, 2007; Agüero \& Marks, 2008, 2011; Cáceres-Delpiano, 2012) : $^{2}$

Such negative association between fertility and labor supply may not exist in developing countries, where extended families with three generations living in one household are common (Rosenzweig \& Wolpin, 1985, Chu et al., 2011) ? $^{3}$ For extended families, the effect of fertility on parental labor supply depends on the substitutability between grandparents' time and parents' time in caring for children. Because the time cost of grandparents is lower than that of parents, in response to the increase in fertility, grandparents may move to live with their children and grandchildren, increasing their time allocated to childcare and household chores. In this scenario, household structure endogenously responds to the change in fertility, and parental labor supply does not necessarily decrease with fertility. Unfortunately, no prior study has addressed the issue of mediating role of extended families in examining the effects of fertility on parental labor supply.

This paper aims to test the effects of fertility on parental labor supply with particular attention to the mediating role of childcare provided by grandparents in extended families. Drawing on

\footnotetext{
${ }^{1}$ The empirical literature testing the causal effects of fertility on parental labor supply from developed countries is in abundance (Cain, 1966, Fleisher \& Rhodes, 1979; Cramer, 1980; Rosenzweig \& Wolpin, 1980; Willis, 1987; Angrist \& Evans 1998 Ebenstein 2009). See also two survey papers by Nakamura \& Nakamura (1992) and Browning (1992).

${ }^{2}$ The empirical literature from developing countries is relatively small (Cruces \& Galiani, 2007, Agüero \& Marks, 2008, 2011; Cáceres-Delpiano, 2012). Using twinning as a natural experiment, Cáceres-Delpiano (2012) finds that although fertility decreases labor supply for mothers with more schooling years and living in urban areas, it does not have a significant effect on maternal labor supply for residents from rural areas and from Asia. We provide an explanation for the insignificant effect on maternal labor supply for residents in Asia in Cáceres-Delpiano (2012). Following Angrist \& Evans (1998), Cruces \& Galiani (2007) uses the sex composition of the first two children as an instrument for fertility. They find that fertility decreases the labor supply of women in Argentina and Mexico.

$\sqrt[3]{\mathrm{Chu} \& \mathrm{Yu}}$ (2009) show that more than $20 \%$ of the Chinese rural households live with three generations. Within the first few years after the marriage of young adults, $72 \%$ of them live with their parents. Furthermore, the parents of husbands and the young couples usually live in the same village even if they do not live together. Rosenzweig \& Wolpin (1985) find that $62 \%$ of all farm households in rural India contain at least two generations of adult kin.
} 
data from rural China, we not only test whether parental labor supply changes with the increase in fertility, but also examine whether household structure responds to the increase in fertility. To our best knowledge, this study is the first to rigorously identify the effect of fertility on household structure 4

To address the issue of endogenous fertility decisions, following Rosenzweig \& Wolpin (1980), we use twinning as a natural experiment for fertility $5^{5}$ Employing the self-collected Chinese child twin survey (CCTS), we find that fertility does not have a negative effect on parental labor supply. By contrast, we find that the twinning-induced rise in fertility increases the probability of coresidence of grandparents. Specifically, an increase of one additional child induced by twinning raises the probability of coresidence of grandparents by 16-29 percentage points. The results remain robust when we use the 1990 Chinese population census as an alternative data source. Therefore, the empirical evidence is consistent with the hypothesis that the childcare provided by grandparents mitigates the negative effect of fertility on parental labor supply.

Our study not only contributes to the traditional literature on fertility and parental labor supply but also to a strand of more recent literature on the role of grandparental coresidence in family behavior. Zeng \& Xie (2014) finds that the educational level of coresident grandparents directly affects the educational attainment of their grandchildren in China. The effect size is similar to that of parental education. The result in Zeng \& Xie (2014) corroborates our analysis by showing empirical evidence on the importance of grandparental child care in China. Chu et al. (2014)

\footnotetext{
${ }^{4}$ In a chapter about fertility and family behavior in the Handbook of Development Economics, Schultz (2010) lists the effect of fertility on household living arrangements as an important but under-studied research topic. Many studies have examined the effect of household structure on the labor supply of women (Tienda \& Glass, 1985; , Wong \& Levine, 1992; Gong \& Van Soest, 2002; Maurer-Fazio et al., 2011; Posadas \& Vidal-Fernández, 2012). They find that the coresidence of grandparents increases the labor supply of women who have children. However, no one has explicitly addressed the mediating role of the childcare provided by grandparents in the relationship between fertility and parental labor supply in extended families.

${ }^{5}$ To tackle this endogeneity problem, the literature has mainly used two methods based on natural experiments. Rosenzweig \& Wolpin (1980) use the natural occurrence of twinning at the first birth parity to identify the effects of fertility on labor supply. They find that, although women who have had twins do withdraw temporarily from the labor market, their life-cycle labor supply is not affected. See also Bronars \& Grogger (1994) for making use of twins for identification. Angrist \& Evans (1998) use parental preferences for a mixed sex composition of children to construct instrumental variables estimating the effects of fertility on labor supply. They find fertility has a negative effect on the labor supply of women. Recently, Agüero \& Marks (2011) advance a new instrument for family size, infertility. Based on data from 27 mid- and low-income countries, their estimation results show that the presence of children affects neither the likelihood of work nor its intensity for women.
} 
studies the time to first birth by treating coresidence with husbands parents and labor supply as endogenous. After controlling for endogeneity they find that both coresidence and working are associated with a delay in childbearing. We treat fertility as endogenous. Using twinning as a natural experiment, we find that the increase in fertility enhances significantly the coresidence of grandparents, but does not significantly affect parental labor supply.

Our findings have important policy implications. One major cost of fertility is parental labor supply (or more generally, parents' time). Our findings suggest that with the help of grandparents, fertility does not negatively affect parental labor supply, suggesting that as an informal childcare provision mechanism, extended family plays an important mitigating role for the time cost of children. However, with the decline of the extended family in China, as well as in other developing countries, the time cost of children will increase for parents, which will exert a further downward pressure on China's low fertility rate. This fact calls for a few policy considerations. First, governments in developing countries should establish a public childcare system to supplement the declining informal system. The recent literature from Canada suggests that the highly subsidized and universally accessible childcare significantly increase maternal labor supply (Baker et al., 2008, Lefebvre \& Merrigan, 2008). Such services are often not available in developing countries. Second, China should relax the one-child policy further, because with the decline of extended families, fertility may continue to fall from the current low level of $1.46^{6}$ The one-child policy was relaxed in 2014 to allow couples to have two children if one of the couples is the only child of his/her family. However, such a relaxation may not be enough to stop the declining trend of total fertility rates as the costs of children continue to increase in China.

The rest of the paper is structured as follows. In Section 2, we introduce the CCTS data. In Sections 3 and 4, we present our main estimation results by testing the effects of fertility on parental labor supply and household structure. In Section 5, we examine the role of coresidence of grandparents in estimating the effect of fertility on parental labor supply. In Section 6, we conduct the robust analysis. Section 7 concludes the study.

Ebenstein 2010, 2011) studies the socioeconomic consequences of the one-child policy on sex ratio imbalance in China. 


\section{Data}

This section first introduces the CCTS data. We then discuss the distribution of fertility in the data. Finally, we describe main variables for our empirical analysis.

\subsection{The Chinese child twin survey}

In this paper, we use data from the CCTS. The Urban Survey Unit (USU) of the National Bureau of Statistics conducted the survey in late 2002 and early 2003 in Kunming, China. Kunming, which is the capital city of Yunnan Province, has 14 county-level administrative units and a total population of about 5.3 million, with $65 \%$ of them living in rural areas. Yunnan is located in the far southwestern corner of China and is a relatively under-developed province. The average per capital GDP was RMB 5,800 in Yunnan, in contrast to an average RMB 10,000 in China in 2002.

To the best of our knowledge, CCTS is the first census-type survey on households with twin children. Its sampling and survey design has three important features. First, the survey includes almost all households with twin children 6-18 years old living in Kunming in 2002. The USU initially identified the households with twin children on the basis of the 2000 population census, according to whether the children have the same birth year and month and whether they have the same relationship with the household head. The addresses of these households are then obtained from the census office, and a visit to the household verifies the presence of twins. Starting from 2,300 pairs of potential twins identified in the census, 1,694 households with twin children are successfully interviewed. See Rosenzweig \& Zhang (2009) and Yi et al. (forthcoming) for a detailed description of the CCTS.

Second, for comparison, the survey contains a probability sample of households with nontwin children in the same age range. Specifically, for every twin household identified, the fourth household on the right-hand side of the same block was chosen to locate a non-twin household. If the fourth household does not have at least one child in the age range of 6-18, interviewers would continue going to the fifth, sixth, and so on. As many as 1,693 non-twin households provide 
information in the survey.

Finally, the survey covers an extensive range of information about family structure and parental labor supply, in addition to a wide range of demographic, social, and economic information at both the individual and household level. The questionnaire contains household, parents, and children modules, which are answered by household heads, parents, and children, respectively. More importantly, it contains information on children's birth weight. We can thus control for differences in endowments between twins and singletons in estimating the effect of fertility on household structure and parental labor supply.

We restrict our sample to households living in rural areas and with the eldest child less than 16:7 Thus, all children are born after the one-child policy in 1979. We have a total of 1,894 qualified households with intact information for our empirical analysis.

\subsection{The Distribution of Fertility by Twinning Status}

The specifics and the enforcements of the one-child policy vary from one place to another in China (Li et al., 2011). In Kunming, rural households are exempted from the strict one-child policy. The population policy regulated that rural households can have at most two children, although they are encouraged to have only one (Family Planning Commission of Yunnan Province, 2003). So the population policy in rural Kunming is actually a "two-child" policy. Table 1 shows the distribution of fertility based on the CCTS data. In this table, we categorize the sample into three groups: nontwin households (Column(1)), households with twin children only at the first birth parity (Column (2)), and households with twin children only at the second parity (Column (3)). Column (1) shows that about $37 \%$ of non-twin households have more than one child, but less than $1 \%$ of the group have more than two children. For households with twinning at the first birth parity, more than 93\% have two children only (Column (2)). Finally, for households with twinning at the second birth parity, all of them have three children only except one household (Column (3)). In sum, we conclude that the population policy has been strictly enforced in rural Kunming. Therefore,

\footnotetext{
${ }^{7}$ Age 16 is the legally minimum age for working in China. So we minimize the possibility that child has contributed to household production or to family farm and enterprise by restricting children's age to be less than 16.
} 
twinning accounts for a substantial part of the variation in fertility in the CCTS data.$^{8}$

\subsection{Variable Description}

Table 2 summarizes the descriptive statistics of main variables. The CCTS covers detailed information on parental labor supply. It includes not only parental work status, but also work time. Moreover, the survey provides information on parental work type, migration status, and earnings. Parental work status is a dummy variable indicating whether a parent worked on his or her own farm or took a non-agricultural job in 2002. Column (1) shows that $78 \%$ of mothers and $85 \%$ of fathers worked. The probability of working was higher for fathers than mothers. Regarding working time, we have two variables. One is measured by the number of days per month, and the other is number of hours per week. We find that both mothers and fathers worked about 20 days per month, but mothers worked fewer hours per week: 37 versus 41 for fathers. Columns (3) and (5) show the means of variables for twin and non-twin families, respectively. We find little differences in work status and work time for mothers between these two types of families. Regarding paternal work status, the probability of working is 3 percentage points higher in non-twin families than that in twin families. But this difference is statistically insignificant. Finally, the difference in paternal working hours between twin and non-twin families is very small.

Fertility may affect not only parental work status and work time but also work type. In the survey, respondents also provide information about the work type. Specifically, we use two dummy variables to measure parental work type. The first one indicates whether parents worked on their own farm. Column (1) shows that $59 \%$ of mothers and $55 \%$ of fathers worked on farm. The other variable indicates whether parents run private businesses 9 We call parents who run private businesses entrepreneurs. We find that $25 \%$ and $26 \%$ of mothers and fathers, respectively, were entrepreneurs. Regarding these two variables, Columns (3) and (5) show no significant differences between parents in non-twin and twin families.

\footnotetext{
${ }^{8}$ Almost all families have three children or fewer in the CCTS. We thus exercise caution in generalizing our results based on China to countries with very high fertility.

${ }^{9}$ Private business does not include working on families' own land.
} 
We also check the effects of fertility on parental migration status and earnings due to the richness of the data. The variable "migrant" is defined as one if a parent worked and left the home village for at least six months in 2002. Otherwise, it equals zero. We find that $3 \%$ of mothers and $5 \%$ of fathers were migrants. As far as earnings are concerned, Column (1) shows that fathers earned substantially more than mothers in rural Kunming. Mothers earned about RMB 370 per month. By contrast, fathers earned RMB 600. Columns (3) and (5) show significant differences in these two variables between twin and non-twin families. Specifically, both parents from twin families were more likely to be migrants, but fathers from non-twin families earned more.

We use four variables to measure family structure. The first one is the number of both paternal and maternal grandparents living in the family in 2002. The average number of coresiding grandparents is 0.25 . The second one is a dummy variable indicating whether a household had at least one coresiding grandparent. Table 2 shows that $13 \%$ of households live with at least one grandparent. The third and fourth variable is about the coresidence of other adult relatives such as aunts and uncles.$^{10}$ Columns (3) and (5) show the probabilities of coresiding with grandparents and other adult relatives are significantly higher for twin than for non-twin families. For example, the probability of living with grandparents is about 11 percentage points higher in twin families than non-twin families.

We use another four variables to measure parental characteristics: maternal age, age at the first birth, schooling years, and ethnicity. Table 2 shows that mothers on average were 36 years old in 2002, had their first children at age 24, and have 8 years of education; $82 \%$ are Han Chinese. Comparing Column (5) with (3), we find that mothers with twin children were older in 2002, had their first children at older ages, have less schooling years, and are less likely to be Han Chinese. But a simple $t$-test shows these differences are statistically insignificant between non-twin and twin families.

Finally, we use birth weight as a proxy variable of child prenatal endowments. Twins usually have inferior prenatal endowments such as birth weight than singletons. As our data show, twins

\footnotetext{
${ }^{10}$ The CCTS data contain no families that formally hired domestic helpers.
} 
are on average more than 0.5 kilograms lighter than singletons at birth. If we do not control for birth weight, the endowment effects may contaminate estimates using twinning as a natural experiment to identify the causal effect of fertility on household outcomes (Rosenzweig \& Zhang, 2009). We address this concern using the CCTS data because we can directly control for birth weight in all regressions.

\section{The Effect of Fertility on Parental Labor Supply}

To test the effects of fertility on parental labor supply, we estimate the following equation:

$$
y_{i}=\alpha_{0}+\alpha_{1} n_{i}+X_{i} \alpha_{2}+\alpha_{3} b w_{i}+\epsilon_{i}
$$

The dependent variable, $y_{i}$, is a measure of parental labor supply in household $i$. The measures of parental labor supply are discussed in the section above. The key independent variable, $n$, is fertility or the number of children. $X$ refers to a vector of maternal characteristics, including age, age squared, age at the first birth, schooling years, and ethnicity. $b w$ is children's average birth weight in the family. $\epsilon$ is an error term.

\subsection{OLS Estimates Using the Non-twin Sample}

We estimate the effects of fertility on parental labor supply. We first conduct ordinary least squares (OLS) estimations of Equation 1 using the sample of non-twin households only. We have a total of 969 non-twin households in the sample (Column (1) in Table 1). We are interested in the estimate of $\alpha_{1}$, which measures the effect of fertility on labor supply.

The first two columns of Table 3 report the estimates of Equation 1. Due to space limitations, we only report the estimated coefficients on $\alpha_{1}$ in Equation 1 for different dependent variables (labor supply measures). In all regressions, we control for children's average birth weight and maternal age, age squared, age at the first birth, schooling years, and ethnicity.

Our OLS estimates show that fertility is negatively correlated with parental labor supply, which 
is consistent with the prior literature (Angrist \& Evans, 1998; Agüero \& Marks, 2011). In terms of work status, with an additional child, the probability of working decreases by 6 percentage points for mothers and 5 percentage points for fathers. The estimates are statistically significant at the $5 \%$ level. Regarding working time, both parents worked one day less per month with an additional child. The estimates are statistically significant at the $10 \%$ level. Parental working hours per week also decreased with fertility, but the estimates are statistically insignificant.

Fertility is also negatively correlated with parental work type, migration, and earnings. Both parents with more children are more likely to work on a farm, although the estimates are statistically insignificant. Moreover, parents with more children are significantly less likely to be entrepreneurs. With an additional child, the probability of running their own business decreases by about 14 percentage points for both parents. As for migration status, with the increase in fertility, parents, particularly mothers, are less likely to be migrants. The probability of being migrants for mothers decreases by 3 percentage points with an additional child. Finally, mothers earned substantially less with the increase in fertility. With an additional child, mothers' monthly earnings decrease by RMB 69, from the average amount of RMB 370. But the correlation between fertility and fathers' earnings is not significant.

\subsection{Estimate: Twinning at the First Birth}

The OLS estimates based on the non-twin sample do not have a causal interpretation because of the endogeneity of fertility. Fertility is endogenous either because it is a household decision determined by unobserved household characteristics, or because labor supply and earnings could affect fertility (Browning, 1992).

Following the literature (Rosenzweig \& Wolpin, 1980), we use twin birth as the identification

method. Specifically, we conduct the instrumental variable (IV) estimations by using twinning at the first birth as an IV. For this purpose, we use a sample that includes non-twin households and households that have twins at the first birth parity. This sample contains a total of 1,666 households (Columns (1) and (2) in Table 1). According to Imbens \& Angrist (1994), this IV estimate can 
be interpreted as a local average treatment effect (LATE). It identifies the treatment effect of an increase in fertility induced by twinning at the first birth parity on parental labor supply. Because 97\% of households in this sample have two or fewer children, the IV estimate of $\alpha_{1}$ basically identifies the causal effect of an increase in fertility from one to two induced by twinning on labor supply.

We first examine whether twinning at the first birth is a valid IV by estimating the impact of twinning on fertility. The results are reported in Table 4. The point estimates suggest that twin families on average have 0.7 more children. The heteroscedasticity-robust $t$-statistics are almost 40 in both columns, suggesting the IV is highly correlated with fertility (Stock \& Yogo, 2002). The R-squared is 0.42 in Column (1), suggesting twinning alone can explain $42 \%$ of the variation in fertility. To test the exogeneity of twinning at the first birth parity, we carry out a DurbinWu-Hausman test. If twinning is not correlated with maternal characteristics, the estimates of $\alpha_{1}$ should be the same in Columns (1) and (2). The Durbin-Wu-Hausman test statistic reported in Column (2) suggests we cannot reject the null hypothesis that twinning is uncorrelated with maternal characteristics included in Column (2).

The IV estimates reported in Columns (3) and (4) in Table 3 suggest that fertility has no effect on parental labor supply, which is in stark contrast to the OLS estimates (Columns (1) and (2)). Most of the estimates of $\alpha_{1}$ are statistically insignificant. In three cases, the variable fertility is statistically significant but the signs are positive. Fertility induced by twinning at the first birth parity increases the probability of migration for both parents and increases mothers' earnings. ${ }^{11}$

Using twinning as an identification for fertility raises concerns. First, prenatal endowments such as child birth weight are generally inferior for twins than for singletons, and thus twinning may have an effect on family behavior through endowments besides fertility (Rosenzweig \& Zhang, 2009). Following Rosenzweig \& Zhang (2009), we address this concern directly by controlling for child birth weight in estimating Equation 1.

Second, the incidence of twinning is higher among mothers undergoing fertility treatments,

\footnotetext{
${ }^{11}$ The unexpected increase in fertility raises household financial burdens. Because the childcare is partly compensated by grandparents, parents may migrate from rural to urban areas and earn more.
} 
which may invalidate it serving as an IV. However, this concern does not apply to our sample. Kunming is a less developed area in China. Fertility drugs were not available in the 1980s and 1990s ${ }^{12}$ Furthermore, the Durbin-Wu-Hausman test statistics reported in Table 4 show the estimated coefficients on twinning are almost the same for Columns (1) and (2), suggesting that the incidence of twinning is uncorrelated with maternal characteristics.

Third, Rosenzweig \& Wolpin (1980, 2000) suggest twinning does not affect parental life-cycle labor supply, especially at the first birth, because the subsequent fertility is lower for families with twinning, and complete fertility is not affected. However, twinning does affect complete fertility in China, because most households have fewer children under the one-child policy than their optimal fertility level without the constraint. Thus, twinning serves as a good natural experiment in increasing fertility in China.

\subsection{The Effect of the Third Child}

Using twinning at the first birth as an IV for fertility, we mainly identify the local treatment effect of fertility increasing from one to two on parental labor supply. The treatment effect of fertility may be heterogenous. The effect of fertility on parental labor supply at a higher fertility may be different from that at a lower fertility. Thus, this section examines the effect of fertility increasing from two to three on parental labor supply.

We estimate the impact of fertility on labor supply using twinning at the second births as an identification. For this purpose, we need to use a sample of households with at least two births, and for twins family, twinning needs to happen at the second births. By restricting the sample to families with at least two births and using twinning at the second birth as an instrument, we make sure that, on average, preferences over family size are the same in the families with twins at the second birth and those with singleton births. Furthermore, in the context of heterogeneity in the impact of family size and individuals behaving as a function of this heterogeneity, restricting the

\footnotetext{
${ }^{12}$ During a follow-up survey of the CCTS project in 2013, one of the authors interviewed many mothers and staff members in the local bureau of statistics in the field work. No one had ever heard about the fertility drugs that can be used to increase the incidence of twinning.
} 
sample to families with at least two births gives a local treatment effect in the upper tail of the fertility distribution.

As shown in Table 1, all but two non-twin families have one or two children (Column (1)), and all but one twin family have three or fewer children (Column (3)). Dropping the two threechild non-twin families and the one four-child twin family, we are left with a sample for which the variation in fertility comes solely from twinning. Because twinning can predict fertility exactly, a simple OLS estimate of $\alpha_{1}$ is causal, or yields a "LATE." It identifies the treatment effect of an increase in fertility from two to three induced by twinning on parental labor supply.

OLS estimation results reported in Columns (5) and (6) of Table 3 are consistent with the IV estimates identified by the first-birth twinning (Columns (3) and (4)): fertility does not lead to a drop in labor supply. Fertility does not have statistically significant effects on parental labor market outcomes except for the two variables of being migrants and entrepreneurs. For these significant estimates, the signs are positive, suggesting parents are more likely to be entrepreneurs and migrants with the increase in fertility.

Summing up the results in Table 3, we conclude that the exogenous increase in fertility induced by twinning does not negatively affect parental labor market outcomes in our sample. This result is consistent with the recent literature on fertility and parental labor supply in rural areas in developing countries (Agüero \& Marks, 2008, 2011; Cáceres-Delpiano, 2012). However, the existing literature does not provide a good answer to why the OLS estimates of the effect of fertility on labor supply variables are negative whereas the IV estimates are different. The literature also does not provide a good answer to why the results in developing countries are different. We will try to provide an answer next.

\section{The Effects of Fertility on Household Structure}

We propose that the negative effect of fertility on parental labor supply is mediated by the childcare provided by grandparents. When the number of children unexpectedly increases due to twinning, 
the family structure may be adjusted. Because their time cost is lower than that of parents, grandparents move into the household, take care of the children, and do the household chores. Under this scenario, parental labor supply does not necessarily decrease with the increase in fertility. To test this hypothesis, this section examines the effect of fertility on the coresidence of grandparents and other adult relatives.

We estimate Equation 1 using the coresidence of grandparents and other adult relatives as dependent variables. The estimates of $\alpha_{2}$ are reported in Table 5. In Column (1), we report the OLS estimates using the sample of non-twin households only. The estimates show that fertility is positively correlated with the coresidence of grandparents and other adult relatives. But the estimates are statistically insignificant. In contrast to Column (1), the estimates reported in Columns (2) and (3) show that the exogenous variation of fertility substantially increases the coresidence of grandparents and other adult relatives. All estimates but one are statistically significant at least at the $10 \%$ level. The magnitudes of the estimates are economically important. For example, Column (2) shows that the probability of grandparents coresiding increases by 29 percentage points when fertility increases from one to two, induced by twinning at the first birth parity. This probability increases by 15 percentage points when fertility increases from two to three (Column (3)) induced by twinning at the second birth parity.

The results in Table 5 can help explain the positive effects of fertility on the probability of parents being migrants and entrepreneurs. A scale effect of grandparental time might be present on childcare. The time grandparents spend taking care of, for example, two grandchildren is less than the time they spend taking care of only one multiplied by two. When grandparents move into the household with the increase in fertility, parental time spent on childcare and household chores probably decreases. Therefore, parental time in the labor market might be more and flexible.

Summarizing the results reported in Table 5, we find that the exogenous increase in fertility induced by twinning enhances the coresidence of grandparents and other adult relatives. This result is consistent with our prediction. With the increase in fertility, grandparents move into the household to take care of their grandchildren. We propose that the omitted variable of parental 
preference for working can explain the negative bias with the OLS estimates reported in Column (1) of Table 5. When parents have a stronger preference for working, they prefer having fewer children. At the same time, they have a higher demand for grandparental time on childcare and household chores $\sqrt[13]{13}$ Therefore, the potential omitted variable of parental preference for working may negatively correlate with fertility but positively correlate with the coresidence of grandparents, leading to a negative bias in the OLS estimates.

One limitation with the CCTS is that it does not contain information on grandparental childcare and household chore time. Using the Chinese nutrition and health survey in 1989, a simple tabulation shows that hours that grandparents spent on childcare and household chores per week doubled when the number of children younger than six increased from one to two (Li et al. 2013). Furthermore, by using the Chinese population policy as a natural experiment, Li et al. (2013) show grandparents' time spent on childcare and household chores increased by 23 hours per week when fertility increased from one to two and more. By contrast, parental time on childcare and household chores increased by only 6 hours. These results support this paper's proposed mediation role of the childcare provided by grandparents.

\section{Fertility, Household Structure, and Parental Labor Supply}

In studying the effect of fertility on parental labor market outcomes, we stress the mediating role of the childcare provided by grandparents. Thus, an examination of the differences in the changes of parental labor market outcomes between families coresiding with grandparents and without grandparents with respect to the twin-induced change in fertility is interesting. Specifically, we interact fertility with the coresidence of grandparents, and estimate the following equation:

$$
l_{i}=\beta_{0}+\beta_{1} n_{i}+\beta_{2} \text { grandparent }_{i}+\beta_{3} n_{i} * \text { grandparent }_{i}+X_{i} \alpha_{4}+\alpha_{5} b w_{i}+v_{i}
$$

\footnotetext{
${ }^{13}$ Formally hiring domestic helpers in rural China is uncommon. For example, no families hired domestic helpers in the CCTS data.
} 
where $l_{i}$ is a measure of parental labor market outcome in family $i$ and grandparents is a dummy variation indicating that at least one grandparent is living in the family. The definitions of variables $n, X$, and $b w$ are the same as in Equation 1. Note that grandparents is a choice variable. Because we do not have an appropriate IV for this variable, we exercise caution in interpreting the estimates of Equation 2.

Table 6 reports the estimation results of Equation 2. To save space, we only report the estimates of $\beta_{1}$ and $\beta_{3}$. Columns (1) and (2) report the IV estimates based on the sample with non-twin families only. The positive estimates of $\beta_{3}$ shows that given the increase in fertility induced by twinning, both parents in families coresiding with grandparents were more likely to work and worked more time than those parents in families living without grandparents. They were more likely to be entrepreneurs and migrants and earned more. The results are consistent with our expectation. However, all the estimates of $\beta_{3}$ are statistically insignificant. Columns (3) and (4) report the OLS estimates based on the sample with non-twin and twinning-at-second-birth families. The signs of the estimates $\beta_{3}$ are inconclusive. All of the estimates of $\beta_{3}$ are statistically insignificant except one. Column (3) shows that with the increase in fertility, mothers in families coresiding with grandparents earned RMB 152 per month more than those living without grandparents. In sum, the results reported in Table 6 provide weak evidence that with an increase in fertility, parents in families coresiding with grandparents supply more labor. As discussed above, given the endogeneity of the coresidence of grandparents, the results are only suggestive.

\section{Robustness Analysis}

In this section, we conduct the robust analysis. The previous section indicates that fertility does not have a negative effect on parental labor supply, but has a positive effect on the coresidence of grandparents and other adult relatives. We need to ensure the results are not subject to the specific data used. Kunming is only one prefecture-level city in China with a total population of about five million, but China has a total population of 1.3 billion. Therefore, based on the Chinese 
1990 population census (1\% sample), we try to replicate the estimation of Equations 1 and 2 using twinning at the first birth parity as an IV ${ }^{14}$ The limitation with the Chinese population census is that it does not have detailed information on individuals' labor supply. We only have information on whether the individual was working in the census year and whether he or she was working in the agricultural sector. By restricting it to households in which (1) parents were household heads. ${ }^{15}$ (2) the maximum maternal age is 36 , and (3) the maximum children's age is 16 , our sample covers 776,391 households with intact information for our empirical analysis.

We report the estimation results in Table 7. In all regressions, we control for maternal age, age squared, age at the first birth, schooling years, and ethnicity. But we are unable to control for child birth weight because the census does not have this information. We cluster the standard errors at the provincial level to deal with any within-province correlation. Panel A in Table 7 reports the IV estimates of the effect of fertility on parental labor supply (Equation 1). Columns (1)-(2) and (4)-(5) show that the twin-induced increase in fertility does not significantly affect parental work status and type. This result is consistent with those using the CCTS data. Columns (3) and (6) show that parents with more children induced by twinning were more likely to be migrants, but the estimates are statistically insignificant. Considering the large sample size, we conclude that having an additional child does not significantly affect parental labor supply.

Panel B reports the effect of fertility on coresidence of grandparents and other adult relatives. Consistent with the estimation results using the CCTS data, we find that fertility increases coresidence of grandparents. The estimates are both statistically and economically significant. For example, with an additional child, the probability of coresiding with at least one grandparent increases by 4.4 percentage points. The magnitude of the estimate is smaller than the one reported in Table 3 using the CCTS data. We thus restrict the sample to households in provinces with lower per capita GDP than the national average level. The estimate increases to about 9 percentage points ${ }^{16}$

\footnotetext{
${ }^{14}$ The first-stage estimation results show that the IV is statistically significant with a $t$-statistic of 22 in the fertility equation. The results suggest our estimates do not suffer from the weak instrument variable problem. To save space, we do not report these results here.

${ }^{15}$ We can only identify children of household heads in the census.

${ }^{16}$ The result is not reported in the able, but is available upon request.
} 
Different from the results reported in Table 3, Columns (9) and (10) in Table 7 show that fertility does not significantly affect coresidence of other adult relatives.

Using the census data, we then estimate Equation 2 and report the results in Panel C of Table 7. Column (11) shows interesting results. With an additional child induced by twinning, the probability of working decreased by about 3 percentage points for mothers in families not coresiding with grandparents. The estimate of $\beta_{1}$ is statistically significant at the $10 \%$ level. By contrast, the probability of working increased by almost 3 percentage points for mothers living with grandparents $\left(\beta_{1}+\beta_{3}=0.03\right)$. The Wald test statistic is statistically significant at the $5 \%$ level, rejecting a null hypothesis that $\beta_{1}+\beta_{3}=0$. Regarding paternal labor supply, the basic pattern reported in Column (11) remains in Column (15). But the estimates reported in Column (15) are statistically insignificant.

Summing up the results reported in Table 7, we conclude that on one hand, the twinninginduced increase in fertility does not negatively affect parental labor supply. On the other hand, the increase in fertility significantly enhances coresidence of grandparents. The result is consistent with the one using the CCTS data. Moreover, with the increase in fertility, the probability of working increases for parents living with grandparents.

\section{Discussion and Conclusion}

This paper examines the effects of fertility on household structure and parental labor supply in rural China where extended families are prevalent. To address the endogeneity problem, we use the CCTS data. It is a unique survey on households with twin children and a comparison group of non-twin households as well. Based on this data set, although a negative correlation exists between fertility and parental labor supply, we find no evidence about the negative effects of fertility on parental labor supply by using twinning as a natural experiment. By contrast, we find that the twinning-induced increase in fertility significantly enhances the coresidence of grandparents. When we use the Chinese 1990 population census, the results main robust. In rural China, where 
extended families are prevalent, non-parental household members and especially grandparents provide childcare. Therefore, the childcare provided by grandparents mitigate the negative effects of fertility on parental labor supply.

The findings in this paper have important policy implications. The one-child policy is currently subject to heated debate in both academic research and government policy making. We show that reducing fertility cannot increase labor supply, and thus, it does not help to increase the immediate income. This finding means, in the short or medium run, that China's birth control policy may not contribute to the growth of GDP. The lower fertility might have led to better child quality, and this improved human capital will promote the economic growth of China in the long run. However, Rosenzweig \& Zhang (2009) conclude that the contribution of the one-child policy in China to the development of its human capital is modest at best.

The results of our paper also shed light on the understanding of the aggregate socioeconomic changes in developing countries, in particular the comovements of fertility, household structure, labor supply, and economic development. The prevalence of extended families decreases with economic development (Chu \& Yu, 2009). With the decrease in extended families, fertility would have a bigger effect on labor supply. Thus, the decline of the extended family could be a factor weighing against economic development (or women's labor force participation) because it allows prime-age adults not to have to withdraw from the labor market to have children. Furthermore, the decline of extended families could be one reason fertility decreases with economic development. That is, having a child now means more parents leave the labor force because grandparents are no longer around to take care of the child while parents work. Government-subsidized childcare is needed to compensate for the negative effects of the decrease in childcare service from grandparents on parental labor supply. However, the causality could also run from the reverse direction as shown in the paper. The decrease in fertility causes the decline in extended family, because there is less demand for childcare from grandparents. In this sense, our paper is just a starting point to explore the interplays between fertility, household structure, and labor supply during the economic development process. Future research along this direction is highly desirable. 


\section{References}

Agüero, Jorge M, \& Marks, Mindy S. 2008. Motherhood and female labor force participation: evidence from infertility shocks. The American Economic Review, 500-504.

Agüero, Jorge M, \& Marks, Mindy S. 2011. Motherhood and female labor supply in the developing world: Evidence from infertility shocks. Journal of Human Resources, 46(4), 800-826.

Angrist, Joshua D, \& Evans, William N. 1998. Children and their parents' labor supply: Evidence from exogenous variation in family size. The American Economic Review, 88(3), 450-477.

Baker, Michael, Gruber, Jonathan, \& Milligan, Kevin. 2008. Universal childcare, maternal labor supply, and family well-being. The Review of Economic Studies, 116(4), 709-745.

Borjas, Gorge. 2000. Labor Economics. McGraw-Hill.

Bronars, Stephen G, \& Grogger, Jeff. 1994. The economic consequences of unwed motherhood: Using twin births as a natural experiment. The American Economic Review, 1141-1156.

Browning, Martin. 1992. Children and household economic behavior. Journal of Economic Literature, 1434-1475.

Cáceres-Delpiano, Julio. 2012. Can we still learn something from the relationship between fertility and mothers employment? Evidence from developing countries. Demography, 49(1), 151-174.

Cain, Glen G. 1966. Married women in the labor force: An economic analysis. University of Chicago.

Chu, CY, Xie, Yu, \& Yu, Ruoh Rong. 2011. Coresidence with elderly parents: A comparative study of southeast China and Taiwan. Journal of Marriage and Family, 73(1), 120-135.

Chu, CY, Kim, Seik, \& Tsay, Wen-Jen. 2014. Coresidence with husbands parents, labor supply, and the duration to first birth. Demography, 51, 185-204. 
Chu, CY Cyrus, \& Yu, Ruoh-Rong. 2009. Understanding Chinese families: A comparative study of Taiwan and southeast China. Oxford University Press.

Cramer, James. 1980. Fertility and female employment: Problems of causal direction. American Sociological Review, 167-190.

Cruces, Guillermo, \& Galiani, Sebastian. 2007. Fertility and female labor supply in Latin America: New causal evidence. Labour Economics, 14(3), 565-573.

Ebenstein, Avraham. 2009. When is the local average treatment close to the average? Evidence from fertility and labor supply. Journal of Human Resources, 44(4), 955-975.

Ebenstein, Avraham. 2010. The "missing girls" of China and the unintended consequences of the one child policy. Journal of Human Resources, 45(1), 87-115.

Ebenstein, Avraham. 2011. Estimating a dynamic model of sex selection in China. Demography, 48(2), 783-811.

Family Planning Commission of Yunnan Province. 2003. Regulations on population and family planning in Yunnan Province. China Population Press.

Fleisher, Belton M, \& Rhodes, George F. 1979. Fertility, women's wage rates, and labor supply. American Economic Review, 69(1), 14-24.

Gong, Xiaodong, \& Van Soest, Arthur. 2002. Family structure and female labor supply in Mexico City. Journal of Human Resources, 163-191.

Imbens, Guido W, \& Angrist, Joshua D. 1994. Identification and estimation of local average treatment effects. Econometrica, 467-475.

Killingsworth, Mark R, \& Heckman, James J. 1986. Female labor supply: A survey. Handbook of Labor Economics, 1, 103-204. 
Lefebvre, Pierre, \& Merrigan, Philip. 2008. Child-care policy and the labor supply of mothers with young children: A natural experiment from Canada. Journal of Labor Economics, 26(3), $519-548$.

Li, Hongbin, Yi, Junjian, \& Zhang, Junsen. 2011. Estimating the effect of the one-child policy on the sex ratio imbalance in China: identification based on the difference-in-differences. Demography, 48(4), 1535-1557.

Li, Hongbin, Yi, Junjian, \& Zhang, Junsen. 2013. Fertility and parental labor supply in a developing country: Identification based on a unique population policy. Working paper.

Maurer-Fazio, Margaret, Connelly, Rachel, Chen, Lan, \& Tang, Lixin. 2011. Childcare, eldercare, and labor force participation of married women in urban China, 1982-2000. Journal of Human Resources, 46(2), 261-294.

Nakamura, Alice, \& Nakamura, Masao. 1992. The econometrics of female labor supply and children. Econometric Reviews, 11(1), 1-71.

Posadas, Josefina, \& Vidal-Fernández, Marian. 2012. Grandparents' childcare and female labor force participation. IZA discussion paper.

Rosenzweig, Mark R, \& Wolpin, Kenneth I. 1980. Life-cycle labor supply and fertility: causal inferences from household models. Journal of Political Economy, 88(2), 328-48.

Rosenzweig, Mark R, \& Wolpin, Kenneth I. 1985. Specific experience, household structure, and intergenerational transfers: farm family land and labor arrangements in developing countries. The Quarterly Journal of Economics, 961-987.

Rosenzweig, Mark R, \& Wolpin, Kenneth I. 2000. "Natural” natural experiments. Journal of Economic Literature, 38(4), 827-874.

Rosenzweig, Mark R, \& Zhang, Junsen. 2009. Do population control policies induce more human 
capital investment? Twins, birth weight and China's one-child policy. The Review of Economic Studies, 76(3), 1149-1174.

Schultz, T Paul. 2010. Population policies, fertility, women's human capital, and child quality. Handbook of Development Economics, 4, 3249-3303.

Stock, James H, \& Yogo, Motohiro. 2002. Testing for weak instruments in linear IV regression. National Bureau of Economic Research.

Tienda, Marta, \& Glass, Jennifer. 1985. Household structure and labor force participation of black, Hispanic, and white mothers. Demography, 22(3), 381-394.

Willis, Robert J. 1987. What have we learned from the economics of the family? American Economic Review, 77(2), 68-81.

Wong, Rebeca, \& Levine, Ruth E. 1992. The effect of household structure on womens economic activity and fertility: evidence from recent mothers in urban Mexico. Economic Development and Cultural Change, 41(1), 89-102.

Yi, Junjian, Heckman, James J, Zhang, Junsen, \& Conti, Gabriella. forthcoming. Early Health Shocks, Intrahousehold Resource Allocation, and Child Outcomes. Economic Journal.

Zeng, Zhen, \& Xie, Yu. 2014. The effects of grandparents on childrens schooling: Evidence from rural China. Demography, 51(2), 599-617. 
Table 1: Distribution of fertility in rural Kunming by twinning status

\begin{tabular}{|c|c|c|c|}
\hline & $\begin{array}{l}\text { No twins } \\
\text { (1) }\end{array}$ & $\begin{array}{l}\text { First-birth twins only } \\
\text { (2) }\end{array}$ & $\begin{array}{l}\text { Second-birth twins only } \\
\text { (3) }\end{array}$ \\
\hline One child & $\begin{array}{l}612 \\
(63.16 \%)\end{array}$ & & \\
\hline Two children & $\begin{array}{l}355 \\
(36.64)\end{array}$ & $\begin{array}{l}650 \\
(93.26)\end{array}$ & \\
\hline Three children & $\begin{array}{l}2 \\
(0.21)\end{array}$ & $\begin{array}{l}47 \\
(6.74)\end{array}$ & $\begin{array}{l}227 \\
(99.56)\end{array}$ \\
\hline Four children & & & $\begin{array}{l}1 \\
(0.44)\end{array}$ \\
\hline \# Total families & $\begin{array}{l}969 \\
(100)\end{array}$ & $\begin{array}{l}697 \\
(100)\end{array}$ & $\begin{array}{l}228 \\
(100)\end{array}$ \\
\hline
\end{tabular}

Data source: The Chinese child twin survey

Note: Percentages are in parentheses for each category (column). 
Table 2: Descriptive statistics of variables

\begin{tabular}{|c|c|c|c|c|c|c|}
\hline & \multicolumn{2}{|c|}{$\begin{array}{l}\text { All } \\
\text { families }\end{array}$} & \multicolumn{2}{|c|}{$\begin{array}{l}\text { Non-twin } \\
\text { families }\end{array}$} & \multicolumn{2}{|c|}{$\begin{array}{l}\text { Twin } \\
\text { families }\end{array}$} \\
\hline & $\begin{array}{l}\text { Mean } \\
\text { (1) }\end{array}$ & $\begin{array}{l}\text { SD } \\
(2)\end{array}$ & $\begin{array}{l}\text { Mean } \\
\text { (3) }\end{array}$ & $\begin{array}{l}\text { SD } \\
(4)\end{array}$ & $\begin{array}{l}\text { Mean } \\
(5)\end{array}$ & $\begin{array}{l}\text { SD } \\
(6)\end{array}$ \\
\hline \multicolumn{7}{|l|}{ Maternal labor supply } \\
\hline $\begin{array}{l}\text { Worked (dummy) } \\
\text { Work time }\end{array}$ & & 0.78 & 0.42 \\
\hline Work time (days/month) & 20.06 & 11.46 & 20.00 & 11.31 & 20.11 & 11.63 \\
\hline \multicolumn{7}{|l|}{ Work type } \\
\hline 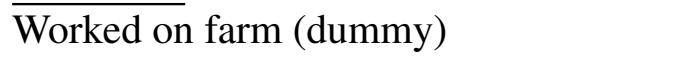 & 0.59 & 0.49 & 0.59 & 0.49 & 0.60 & 0.49 \\
\hline \multicolumn{7}{|l|}{ Migration status } \\
\hline \multicolumn{7}{|l|}{ Earnings } \\
\hline 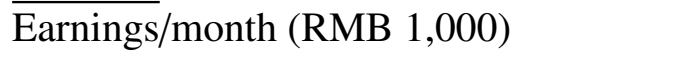 & 0.37 & 0.41 & 0.38 & 0.41 & 0.36 & 0.42 \\
\hline \multicolumn{7}{|l|}{$\begin{array}{l}\text { Paternal labor supply } \\
\text { Work status }\end{array}$} \\
\hline $\begin{array}{l}\text { Worked (dummy) } \\
\text { Work time }\end{array}$ & \multicolumn{5}{|c|}{ Work time } & 0.38 \\
\hline Work time (days/month) & 21.93 & 10.30 & 22.21 & 9.81 & 21.62 & 10.77 \\
\hline $\begin{array}{l}\text { Work time (hours/week) } \\
\text { Work type }\end{array}$ & \multicolumn{5}{|c|}{ Work type } & 23.07 \\
\hline Worked on farm (dummy) & 0.55 & 0.50 & 0.56 & 0.50 & 0.55 & 0.50 \\
\hline \multicolumn{7}{|l|}{ Migration status } \\
\hline $\begin{array}{l}\text { Migrant } \\
\text { Earnings }\end{array}$ & \multicolumn{5}{|c|}{ Earnings } & 0.25 \\
\hline 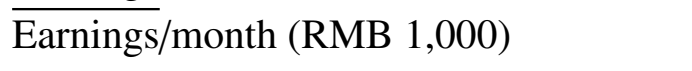 & 0.60 & 0.69 & 0.64 & 0.82 & 0.56 & 0.51 \\
\hline \multicolumn{7}{|l|}{ Household Structure } \\
\hline Co-residence of Grandparents (\#) & 0.22 & 0.48 & 0.12 & 0.26 & 0.30 & 0.61 \\
\hline Co-residence of Grandparents (dummy) & 0.18 & 0.33 & 0.11 & 0.18 & 0.22 & 0.41 \\
\hline Co-residence of other adult (\#) & 0.01 & 0.13 & 0.01 & 0.10 & 0.02 & 0.16 \\
\hline Co-residence of other adult (dummy) & 0.01 & 0.11 & 0.01 & 0.09 & 0.02 & 0.12 \\
\hline
\end{tabular}


Table 2: Descriptive statistics of variables (cont.)

\begin{tabular}{lllllll}
\hline \hline & \multicolumn{3}{l}{ All families } & \multicolumn{2}{l}{ Non-twin families } & \multicolumn{2}{l}{ Twin families } \\
\hline & $\begin{array}{l}\text { Mean } \\
\text { (1) }\end{array}$ & SD & Mean & SD & Mean & SD \\
& $(3)$ & $(4)$ & $(5)$ & $(6)$ \\
\hline & & & & & & \\
Maternal characteristics & & & & & & \\
Maternal age & 35.61 & 4.45 & 34.75 & 4.13 & 36.51 & 4.59 \\
Materna age at first births & 23.91 & 3.52 & 23.48 & 3.04 & 24.35 & 3.92 \\
Maternal schooling years & 7.95 & 2.90 & 8.28 & 2.90 & 7.61 & 2.86 \\
Maternal ethnicity (Han=1) & 0.82 & 0.39 & 0.83 & 0.38 & 0.80 & 0.40 \\
& & & & & & \\
Children characteristics & & & & & & \\
Average birth weight of children (kilogram) & 2.83 & 0.53 & 3.13 & 0.44 & 2.51 & 0.42 \\
Average age of children in a family & 10.96 & 3.05 & 10.45 & 3.13 & 11.50 & 2.87 \\
Age of the eldest child in a family & 11.70 & 3.02 & 11.27 & 2.98 & 12.16 & 2.98 \\
Age of the youngest child in a family & 10.34 & 3.51 & 9.64 & 3.76 & 11.07 & 3.06 \\
\hline
\end{tabular}

Data source: The Chinese child twin survey 
Table 3: OLS and IV estimates of fertility and parental labor supply

\begin{tabular}{|c|c|c|c|c|c|c|}
\hline & \multicolumn{2}{|c|}{ OLS (Non-Twin) } & \multicolumn{2}{|c|}{$\begin{array}{l}\text { IV (Non-Twin and } \\
\text { twining at } 1 \text { st birth) }\end{array}$} & \multicolumn{2}{|c|}{$\begin{array}{l}\text { OLS (Non-Twin and } \\
\text { twining at } 2 \text { nd birth) }\end{array}$} \\
\hline & $\begin{array}{l}\text { Mother } \\
\text { (1) }\end{array}$ & $\begin{array}{l}\text { Father } \\
\text { (2) }\end{array}$ & $\begin{array}{l}\text { Mother } \\
\text { (3) }\end{array}$ & $\begin{array}{l}\text { Father } \\
\text { (4) }\end{array}$ & $\begin{array}{l}\text { Mother } \\
(5)\end{array}$ & $\begin{array}{l}\text { Father } \\
(6)\end{array}$ \\
\hline \multicolumn{7}{|l|}{ Work status } \\
\hline Worked (dummy) & $\begin{array}{l}-0.062 * * \\
(2.04)\end{array}$ & $\begin{array}{l}-0.053 * * \\
(2.04)\end{array}$ & $\begin{array}{l}0.038 \\
(1.08)\end{array}$ & $\begin{array}{l}0.023 \\
(0.76)\end{array}$ & $\begin{array}{l}-0.034 \\
(0.80)\end{array}$ & $\begin{array}{l}-0.020 \\
(0.50)\end{array}$ \\
\hline \multicolumn{7}{|l|}{ Work time } \\
\hline Work time (days/month) & $\begin{array}{l}-1.392^{*} \\
(1.65)\end{array}$ & $\begin{array}{l}-1.343^{*} \\
(1.81)\end{array}$ & $\begin{array}{l}1.065 \\
(1.08)\end{array}$ & $\begin{array}{l}0.845 \\
(0.96)\end{array}$ & $\begin{array}{l}-0.464 \\
(0.39)\end{array}$ & $\begin{array}{l}-0.578 \\
(0.53)\end{array}$ \\
\hline Work time (hours/week) & $\begin{array}{l}-2.013 \\
(1.17)\end{array}$ & $\begin{array}{l}-1.869 \\
(1.18)\end{array}$ & $\begin{array}{l}2.792 \\
(1.39)\end{array}$ & $\begin{array}{l}2.302 \\
(1.22)\end{array}$ & $\begin{array}{l}-1.898 \\
(0.79)\end{array}$ & $\begin{array}{l}-1.577 \\
(0.68)\end{array}$ \\
\hline \multicolumn{7}{|l|}{ Work type } \\
\hline$\overline{\text { Worked on farm (dummy) }}$ & $\begin{array}{l}0.038 \\
(1.17)\end{array}$ & $\begin{array}{l}0.044 \\
(1.30)\end{array}$ & $\begin{array}{l}-0.057 \\
(1.40)\end{array}$ & $\begin{array}{l}-0.059 \\
(1.44)\end{array}$ & $\begin{array}{l}-0.042 \\
(0.90)\end{array}$ & $\begin{array}{l}-0.014 \\
(0.30)\end{array}$ \\
\hline Entrepreneur (dummy) & $\begin{array}{l}-0.137 * * * \\
(4.63)\end{array}$ & $\begin{array}{l}-0.146^{* * * *} \\
(4.70)\end{array}$ & $\begin{array}{l}0.060 \\
(1.59)\end{array}$ & $\begin{array}{l}0.010 \\
(0.26)\end{array}$ & $\begin{array}{l}0.082 * * \\
(2.00)\end{array}$ & $\begin{array}{l}0.076^{*} \\
(1.90)\end{array}$ \\
\hline \multicolumn{7}{|l|}{ Migration status } \\
\hline Migrant & $\begin{array}{l}-0.034 * * * \\
(3.36)\end{array}$ & $\begin{array}{l}-0.022 * * \\
(1.99)\end{array}$ & $\begin{array}{l}0.036 * * \\
(2.41)\end{array}$ & $\begin{array}{l}0.057 * * * \\
(2.96)\end{array}$ & $\begin{array}{l}0.046 * * * \\
(2.74)\end{array}$ & $\begin{array}{l}0.056 * * * \\
(2.72)\end{array}$ \\
\hline \multicolumn{7}{|l|}{ Earnings } \\
\hline $\begin{array}{l}\text { Earnings/month } \\
\text { (RMB 1,000) }\end{array}$ & $\begin{array}{l}-0.069 * * * \\
(2.84)\end{array}$ & $\begin{array}{l}-0.066 \\
(1.28)\end{array}$ & $\begin{array}{l}0.083 * * \\
(2.46)\end{array}$ & $\begin{array}{l}-0.000 \\
(0.01)\end{array}$ & $\begin{array}{l}-0.001 \\
(0.02)\end{array}$ & $\begin{array}{l}-0.026 \\
(0.35)\end{array}$ \\
\hline \# Families & 969 & 969 & 1,666 & 1,666 & 582 & 582 \\
\hline
\end{tabular}

Data source: The Chinese child twin survey

Note: Each cell reports the estimate of $\alpha_{1}$ in Equation 1 from a separate regression. We control for children's average birth weight and maternal age, age squared, age at the first birth, schooling years, and ethnicity in all regressions. Columns (1) and (2) include the non-twin households; Columns (3) and (4) include both non-twin households and households with twin children at the first birth parity only; and Columns (5) and (6) include both non-twin households with exactly two children and twin households with exact three children twinning at the second birth parity. Heteroskedasticity-robust $t$-statistics are in parentheses. $* * * p<0.01,{ }^{*} * p<0.05, * p<0.1$. 
Table 4: OLS Estimates of the determinants of fertility

\begin{tabular}{|c|c|c|}
\hline & $\begin{array}{l}\text { Dependen } \\
(1)\end{array}$ & $\begin{array}{l}\text { variable: \# children } \\
\text { (2) }\end{array}$ \\
\hline Twinning & $\begin{array}{l}0.697 * * * \\
(38.05)\end{array}$ & $\begin{array}{l}0.704 * * * \\
(39.13)\end{array}$ \\
\hline Maternal age & & $\begin{array}{l}0.009 \\
(0.46)\end{array}$ \\
\hline Maternal age squared/100 & & $\begin{array}{l}0.009 \\
(0.35)\end{array}$ \\
\hline Maternal age at the first birth & & $\begin{array}{l}-0.032 * * * \\
(7.72)\end{array}$ \\
\hline Maternal schooling years & & $\begin{array}{l}-0.024 * * * \\
(7.94)\end{array}$ \\
\hline Maternal ethnicity $($ Han=1) & & $\begin{array}{l}-0.153^{* * * *} \\
(5.52)\end{array}$ \\
\hline $\begin{array}{l}\text { Durbin-Wu-Hausman tests } \\
\chi^{2} \text {-statistics } \\
p \text {-values }\end{array}$ & & $\begin{array}{l}0.80 \\
0.37\end{array}$ \\
\hline $\begin{array}{l}\text { Observations } \\
\text { R-squared }\end{array}$ & $\begin{array}{l}1,666 \\
0.418\end{array}$ & $\begin{array}{l}1,666 \\
0.476\end{array}$ \\
\hline
\end{tabular}

Data source: The Chinese child twin survey

Note: The sample includes non-twin households and households with twin children at the first birth parity only. The null hypothesis of the Durbin-Wu-Hausman test reported in Column (2) is that the estimated coefficients on twinning are the same between Columns (1) and (2). Heteroskedasticityrobust $t$-statistics are in parentheses. $* * * p<0.01, * * p<0.05, * p<0.1$. 
Table 5: OLS and IV estimates of fertility and household structure

\begin{tabular}{llll}
\hline \hline & OLS (Non-Twin) & $\begin{array}{l}\text { IV (Non-Twin and } \\
\text { twining at 1st birth) } \\
(2)\end{array}$ & $\begin{array}{l}\text { OLS (Non-Twin and } \\
\text { twining at 2nd birth) } \\
(3)\end{array}$ \\
\hline $\begin{array}{llll}\text { Co-residence of Grandparents } \\
(\#)\end{array}$ & 0.002 & $0.400^{* * *}$ & $0.202^{* * *}$ \\
Co-residence of Grandparents & $(0.08)$ & $(9.11)$ & $(4.66)$ \\
(dummy) & 0.000 & $0.285^{* * *}$ & $0.152^{* * *}$ \\
Co-residence of other adult & $(0.01)$ & $(9.39)$ & $(4.75)$ \\
(\#) & 0.001 & $0.032^{* *}$ & 0.022 \\
Co-residence of other adult & $(0.14)$ & $(2.44)$ & $(1.60)$ \\
(dummy) & 0.004 & $0.026^{* * *}$ & $0.016^{*}$ \\
& $(0.67)$ & $(2.76)$ & $(1.81)$ \\
\# Families & & & 582 \\
\hline
\end{tabular}

Data source: The Chinese child twin survey

Note: Each cell reports the estimate of $\alpha_{1}$ in Equation 1 from a separate regression. We control for children's average birth weight and maternal age, age squared, age at the first birth, schooling years, and ethnicity in all regressions. Column (1) includes the non-twin households; Column (2) includes both non-twin households and households with twin children at the first birth parity only; and Column (3) includes both non-twin households with exactly two children and twin households with exact three children twinning at the second birth parity. Heteroskedasticity-robust $t$-statistics are in parentheses. $* * * p<0.01$, ** $p<0.05, * p<0.1$. 
Table 6: IV and OLS estimates of fertility, household structure, and parental labor supply

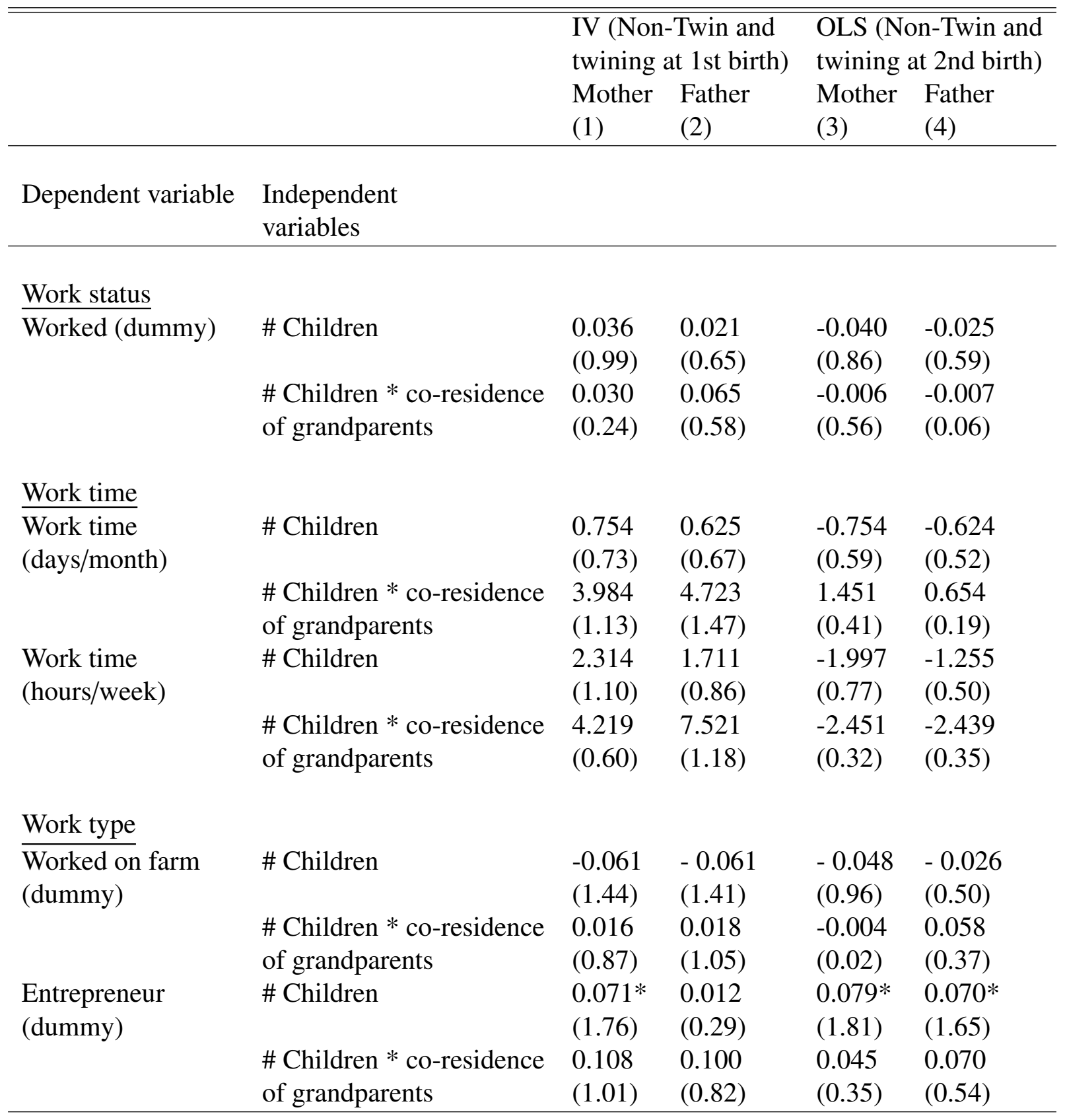


Table 6: IV and OLS estimates of fertility, household structure, and parental labor supply (cont.)

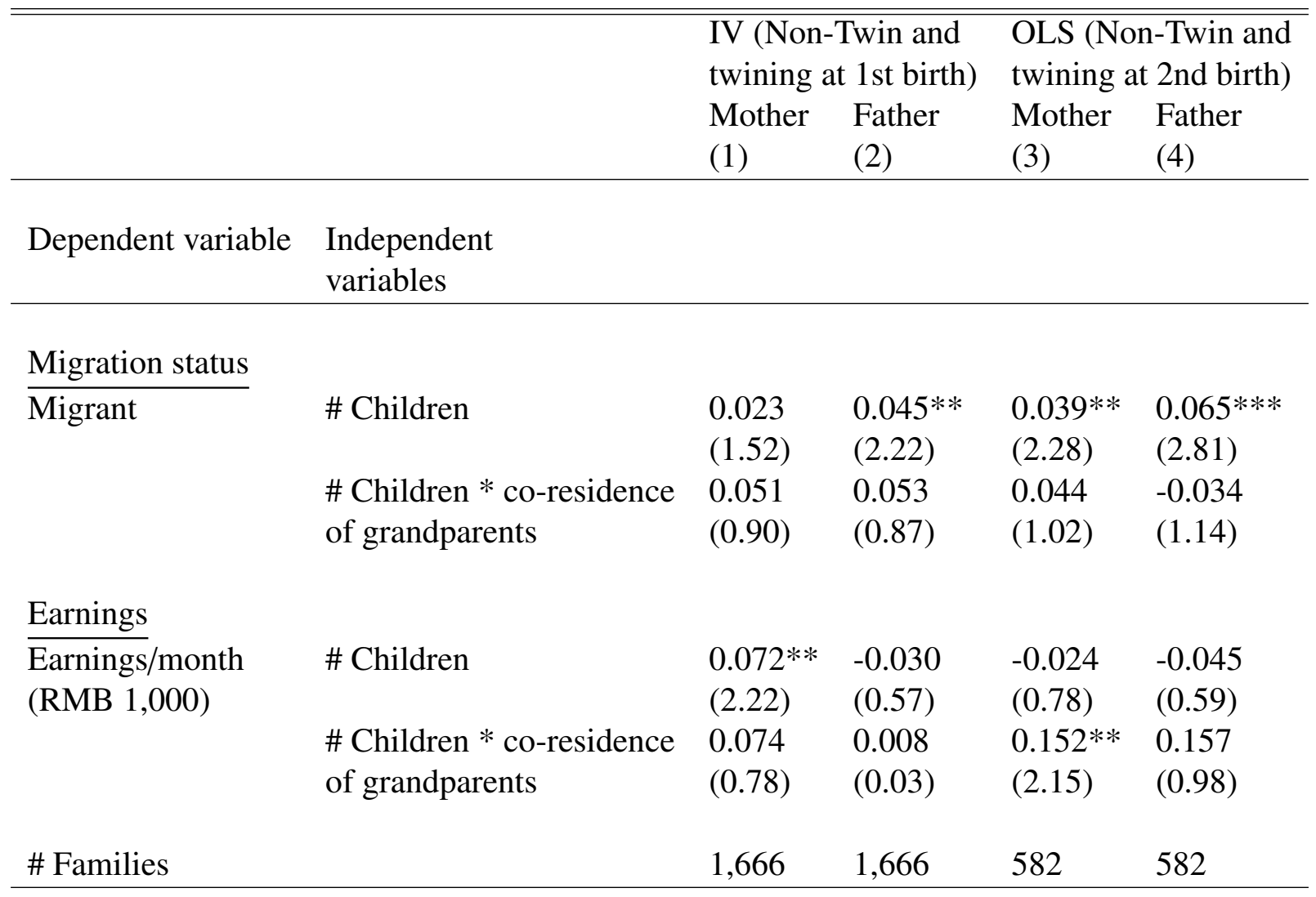

Data source: The Chinese child twin survey

Note: For each dependent variable listed in the left column, we report the estimates of $\beta_{1}$ and $\beta_{3}$ in Equation 2 by sample and parent. Other covariates include children's average birth weight, coresidence of grandparents, and maternal age, age squared, age at the first birth, schooling years, and ethnicity in all regressions. Columns (1) and (2) include both non-twin households and households with twin children at the first birth parity only. Columns (3) and (4) include both non-twin households with exactly two children and twin households with exactly three children twinning at the second birth parity. Heteroskedasticity-robust $t$-statistics are in parentheses. $* * * p<0.01$, ** $p<0.05$, * $p<0.1$. 
Table 7: IV estimates of fertility, household structure, and parental labor supply using Chinese 1990 population census

Panel A: fertility and parental labor supply

\begin{tabular}{ccccccc} 
& Worked & $\begin{array}{c}\text { Mother } \\
\text { Worked } \\
\text { on farm } \\
(1)\end{array}$ & Migrant & Worked & $\begin{array}{c}\text { Father } \\
\text { Worked } \\
\text { on farm }\end{array}$ & Migrant \\
\hline \multirow{3}{*}{ \# Children } & -0.019 & -0.002 & 0.006 & -0.009 & -0.017 & 0.005 \\
& $(1.49)$ & $(0.39)$ & $(1.50)$ & $(1.01)$ & $(1.61)$ & $(1.03)$ \\
\hline
\end{tabular}

Panel B: fertility and household structure

Co-residence of Grandparents Co-residence of other adults \# dummy \# dummy

(7) (8)

(9) (10)

\begin{tabular}{lcccc}
\hline & & & & \\
\# Children & $0.085^{* * *}$ & $0.044 * * *$ & 0.005 & 0.002 \\
& $(4.59)$ & $(3.35)$ & $(0.84)$ & $(0.48)$ \\
\hline
\end{tabular}

Panel C: fertility, household structure, and parental labor supply

\begin{tabular}{|c|c|c|c|c|c|c|}
\hline & $\begin{array}{l}\text { Worked } \\
\text { (11) }\end{array}$ & $\begin{array}{c}\text { Mother } \\
\text { Worked } \\
\text { on farm } \\
(12)\end{array}$ & $\begin{array}{c}\text { Migrant } \\
\text { (13) }\end{array}$ & $\begin{array}{c}\text { Worked } \\
\text { (14) }\end{array}$ & $\begin{array}{c}\text { Father } \\
\text { Worked } \\
\text { on farm } \\
(15)\end{array}$ & $\begin{array}{c}\text { Migrant } \\
\text { (16) }\end{array}$ \\
\hline \# Children & $\begin{array}{c}-0.029 * \\
(1.94)\end{array}$ & $\begin{array}{r}-0.002 \\
(0.26)\end{array}$ & $\begin{array}{c}0.006 \\
(1.07)\end{array}$ & $\begin{array}{l}-0.012 \\
(1.07)\end{array}$ & $\begin{array}{r}-0.016 \\
(1.26)\end{array}$ & $\begin{array}{c}0.002 \\
(0.30)\end{array}$ \\
\hline $\begin{array}{l}\text { \# Children * } \\
\text { co-residence of } \\
\text { grandparents }\end{array}$ & $\begin{array}{c}0.055^{* *} \\
(2.21)\end{array}$ & $\begin{array}{l}-0.003 \\
(0.17)\end{array}$ & $\begin{array}{l}0.006 \\
(0.45)\end{array}$ & $\begin{array}{l}0.016 \\
(0.69)\end{array}$ & $\begin{array}{l}-0.011 \\
(0.42)\end{array}$ & $\begin{array}{l}0.021 \\
(1.10)\end{array}$ \\
\hline \# Families & 776,391 & 776,391 & 776,391 & 776,391 & 776,391 & 776,391 \\
\hline
\end{tabular}

Data source: Chinese 1990 population census.

Note: Each cell in Panels A and B reports the estimate of $\alpha_{1}$ in Equation 1 from a separate regression. For each dependent variable in Panel $\mathrm{C}$, we report the estimates of $\beta_{1}$ and $\beta_{3}$ in Equation 2. Other covariates include the coresidence of grandparents (Panel $\mathrm{C}$ only), and maternal age, age squared, age at the first birth, schooling years, and ethnicity in all regressions. Robust $t$-statistics clustering adjusted at the provincial level are in parentheses. $* * * p<0.01, * * p<0.05, * p<0.1$. 